\title{
Pengaruh Lama Fermentasi terhadap Total Asam, Total Bakteri Asam Laktat dan Warna Kefir Belimbing Manis (Averrhoa carambola)
}

\author{
Sri Mulyani ${ }^{1)}$, Kusuma Melati Faizun Sunarko ${ }^{1)}$, Bhakti Etza Setiani ${ }^{1)}$ \\ ${ }^{1)}$ Program Studi Teknologi Pangan, Fakultas Peternakan dan Pertanian, \\ Universitas Diponegoro, Semarang, Indonesia \\ Email:srimulyani@lecturer.undip.ac.id
}

\begin{abstract}
ABSTRAK
Penelitian ini bertujuan untuk mengetahui pengaruh lama fermentasi terhadap total asam, total bakteri asam laktat dan warna $\mathrm{L}^{*} \mathrm{a} * \mathrm{~b} *$ dari water kefir buah belimbing manis. Rancangan penelitian yang digunakan adalah rancangan acak lengkap (RAL), dengan 4 perlakuan dan 5 kali ulangan. Perlakuan yang diteliti adalah variasi lama fermentasi yaitu 12 jam (t1), 24 jam (t2), 36 jam (t3), dan 48 jam (t4). Water kefir dibuat dari belimbing manis dengan menggunakan grain water kefir sebanyak 5\%, sukrosa sebanyak $8 \%(\mathrm{~b} / \mathrm{v})$. Hasil penelitian menunjukkan bahwa lama fermentasi yang berbeda memberikan pengaruh nyata terhadap total asam, total bakteri asam laktat, nilai $L^{*}$ warna dan nilai $a^{*}$ warna serta tidak berpengaruh secara nyata $(p>0,05)$ pada nilai $b *$ warna. Semakin lama fermentasi dapat meningkatkan total asam, total bakteri asam laktat, nilai $\mathrm{L}^{*}$ warna serta menurunkan nilai a* warna.
\end{abstract}

Kata kunci: Bakteri asam laktat; belimbing manis; water kefir

\section{Fermentation Time Effect on Total Acid, Total Lactic acid Bacteria Color of Star Fruit Water Kefir}

\begin{abstract}
This study aims to determine the effect of fermentation time on total acid, total lactic acid bacteria and color lab of sweet star fruit water kefir. The research design used was a completely randomized design (CRD), with 4 treatments and 5 replications. The experimental treatments were variation of fermentation time of 12 hours (t1), 24 hours (t2),36 hours (t3), and 48 hours (t4). Water kefir is made from sweet starfruit using 5\% water kefir grains and $8 \%$ sucrose. The results showed that different fermentation time had a significant effect on total acid, total lactic acid bacteria, color $\mathrm{L}^{*}$ value and color $\mathrm{a}^{*}$ value and had no significant effect $(\mathrm{p} .0,05)$ on color $\mathrm{b}^{*}$ values. The longer the fermentation will increase the total acid, the total lactic acid bacteria, the $\mathrm{L}^{*}$ color value and decrease the $\mathrm{a}^{*}$ color value.
\end{abstract}

Keywords: Lactic acid bacteria; star fruit; water kefir

(Article History: Received 02-12-2020; Accepted 30-06-2021; Published 21-07-2021)

\section{PENDAHULUAN}

Kesadaran masyarakat terhadap kesehatan yang terus berkembang saat ini menuntut terciptanya pangan yang tidak hanya mengenyangkan namun juga dapat berdampak positif terhadap kesehatan. Kefir merupakan fermentasi susu yang melibatkan sejumlah bakteri penghasil asam laktat (BAL), bakteri penghasil asam asetat dan khamir (Ningsih et al., 2018). Kefir dapat dikategorikan sebagai pangan fungsional karena mengandung probiotik yang dapat memberikan efek kesehatan yang positif bagi yang mengkonsumsinya.
Kefir di Indonesia sudah mulai banyak dikenal sebagai pangan fungsional. Kefir yang dikenal di Indonesia masih sebatas kefir yang berasal dari susu, sedangkan kefir air (water kefir) yang dibuat dengan sari buah masih sangat asing di Indonesia. Water kefir memiliki keunggulan dapat dikonsumsi oleh vegetarian karena tidak menggunakan susu sebagai bahan baku seperti kefir susu. Water kefir merupakan jenis kefir yang terbuat dari bahan dasar cairan yang mengandung gula seperti sari buah dan air gula yang ditambah butir kefir sehingga dapat menghasilkan minuman probiotik yang asam dan 
mengandung sedikit alkohol dari proses fermentasi (Lestari et al., 2018). Manfaat dari water kefir yaitu adanya bakteri probiotik yang dapat memperbaiki proses pencernaan dengan menyediakan mikroflora yang dibutuhkan dan dapat menghambat pertumbuhan bakteri patogen di dalam saluran pencernaan (Muizuddin \& Zubaidah, 2015). Sifat water kefir sangat mirip dengan air, berbeda dengan kefir susu yang kental, hal ini disebabkan karena tidak terdapat protein yang menggumpal oleh asam seperti pada susu.

Belimbing manis (Averrhoa carambola) merupakan salah satu dari berbagai jenis tumbuhan penghasil buah yang berasal dari daerah tropis. Belimbing manis saat ini mulai banyak dibudidayakan di Indonesia dan dapat tumbuh dengan baik, namun pemanfaatan buah belimbing manis masih jarang ditemui. Buah belimbing sangat bermanfaat dalam membantu menurunkan tekanan darah karena mengandung serat, kalium, fosfor, dan vitamin C didalamnya (Berawi \& Pasya, 2016). Buah belimbing memiliki kandungan air sebanyak 90\% (Wiradona \& Prasko, 2018). Hal ini memungkinkan belimbing manis untuk digunakan sebagai bahan dasar pembuatan water kefir.

Pemanfaatan belimbing manis dalam pembuatan pangan fungsional terutama untuk minuman masih sangat sedikit. Pada penelitian sebelumnya ((Sutedjo \& Nisa, 2015) sudah ada pemanfaatan belimbing manis sebagai yoghurt sudah pernah dilakukan dengan lama fermentasi 8 jam, 10 jam dan 12 jam. Keunggulan belimbing manis yaitu dapat mencegah radikal bebas dan hipertensi. Namun pengolahan belimbing manis menjadi water kefir hingga sejauh ini belum pernah dilakukan atau belum pernah ditemukan. Pengolahan belimbing manis menjadi water kefir diharapkan menjadi suatu produk yang dapat disukai konsumen. Proses pembuatan water kefir belimbing yaitu menggunakan metode fermentasi. Penelitian ini bertujuan untuk mengetahui pengaruh lama fermentasi terhadap total asam, total bakteri asam laktat dan warna dari water kefir buah belimbing manis.

\section{METODE PENELITIAN}

$\begin{array}{ccr}\text { Penelitian berlangsung } & \text { selama } \\ \text { periode } & \text { Februari-Juli } 2020 . & \text { Penelitian }\end{array}$

meliputi proses pembuatan water kefir belimbing manis dan pengujian parameter. Parameter yang diuji meliputi total asam, total bakteri asam laktat dan warna $\mathrm{L}^{*} \mathrm{a}^{*} \mathrm{~b}^{*}$.

\section{Pembuatan Water Kefir Belimbing Manis}

Proses pembuatan water kefir buah belimbing manis ini mengacu pada penelitian Insani et al. (2018) dan penelitian Purba et al. (2018) dengan sedikit modifikasi yaitu pada bahan bakunya yang diganti dengan belimbing manis dan perbandingan air dan sari buah belimbing yang berbeda.

Bahan yang digunakan dalam proses ini yaitu air, sari buah belimbing, gula (sukrosa) dan water kefir grain. Proses pembuatan water kefir belimbing manis diawali dengan proses pembuatan sari belimbing. Sari buah belimbing yang telah dibuat selanjutnya dilakukan proses pasteurisasi yaitu dengan perbandingan sari buah belimbing dan air 1:2 . Pasteurisasi dilakukan dengan suhu $71^{\circ} \mathrm{C}$ selama 15 detik (Insani et al., 2018). Setelah selesai dipasteurisasi, kemudian ditambahkan gula sebanyak $8 \%(\mathrm{~b} / \mathrm{v})$ dan dilakukan penurunan suhu hingga mencapai suhu ruang, sari belimbing kemudian diinokulasi dengan penambahan water kefir grain ("Omah Kefir" Ungaran, Semarang) sebanyak 5\% dari total sari buah yang digunakan dalam liter dan diaduk hingga merata secara perlahan, kemudian toples ditutup dan difermentasi sesuai perlakuan lama fermentasi yaitu selama 12 jam (t1), 24 jam (t2), 36 jam (t3), 48 jam (t4). Water kefir yang sudah jadi disaring untuk memisahkan water kefir dan water kefir grain dengan saringan (Purba et al., 2018).

\section{Uji Total Asam}

Pengujian total asam mengacu pada penelitian Rohman et al. (2019) yaitu dilakukan dengan metode titrasi. Langkah awal pengujian total asam yaitu pengambilan sampel water kefir sebanyak $10 \mathrm{ml}$ dan dimasukkan ke dalam erlenmeyer, kemudian sampel ditambahkan indikator phenolphthalein (PP) 1\% sebanyak 2-3 tetes. Sampel dititrasi dengan larutan $\mathrm{NaOH} 0,1 \mathrm{~N}$ hingga warna sampel berubah menjadi merah muda. Volume $\mathrm{NaOH}$ yang digunakan untuk titrasi dicatat. Total asam dapat dihitung dengan menggunakan rumus sebagai berikut : 
Total asam $(\%)=\frac{\mathrm{V} 1 \times \mathrm{N} \times \mathrm{B}}{\mathrm{V} 2 \times 1000} \times 100 \%$

Keterangan:

$$
\begin{aligned}
\mathrm{B} & =\text { Berat molekul asam laktat }(90) \\
\mathrm{N} & = \\
\mathrm{V} 1 & \text { Normalitas } \mathrm{NaOH} \\
& \text { Volume } \mathrm{NaOH} \text { yang digunakan } \\
\mathrm{V} 2 & \quad \text { (ml) }
\end{aligned}
$$

\section{Uji Total Bakteri Asam Laktat (BAL)}

Pengujian total bakteri asam laktat (BAL) mengacu pada penelitian Purba et al. (2018) yaitu dengan cara pengenceran $1 \mathrm{ml}$ sampel dengan larutan $9 \mathrm{ml} \mathrm{NaCl}$ fisiologi $0,85 \%$, kemudian dilanjutkan pengenceran hingga $10^{-6}$ kali. Tiga seri pengenceran terakhir sampel diambil masing masing $1 \mathrm{ml}$ dan dilakukan secara duplo, kemudian dituangkan ke dalam cawan petri yang selanjutnya diisi dengan $15 \mathrm{ml}$ media MRSA (deMan Rogose Sharpe Agar) . Media MRSA yang telah berisi sampel diinkubasi dengan suhu dan lama inkubasi sesuai dengan perlakuan. Cawan diinkubasi dengan menggunakan inkubator bersuhu $37^{\circ} \mathrm{C}$ selama 24 jam dalam posisi cawan terbalik. Jumlah koloni dihitung pada cawan petri yang memiliki jumlah koloni sebanyak 30-300 koloni. Angka total bakteri asam laktat dalam $1 \mathrm{ml}$ adalah dengan mengalikan jumlah koloni pada cawan petri dibagi dengan faktor pengenceran. Hasil analisis mikrobiologi dilaporkan dengan menggunakan Standard Plate Count (SPC).

\section{Uji Warna $L^{*} \mathbf{a}^{*} \mathbf{b}^{*}$}

Pengujian warna mengacu pada penelitian Soetikno et al.(2018) yaitu dengan menggunakan alat chromameter CR 400. Pengujian warna dilakukan dengan memasukkan sampel kedalam tabung silinder dengan diameter $3 \mathrm{~cm}$ dan tinggi $1 \mathrm{~cm}$. Chromameter difokuskan kearah sampel ketika sampel telah dimasukkan. Hasil dari pengukuran akan dinyatakan dalam bentuk nilai $\mathrm{L}^{*}$ (lightness), $\quad \mathrm{a}^{*}$ (redness) dan $\mathrm{b}^{*}$ (yellowness). Nilai $\mathrm{L}^{*} \quad$ (lightness) menunjukkan tingkat kecerahan sampel, makin cerah sampel yang diukur maka nilai $\mathrm{L}^{*}$ mendekati 100, nilai $a^{*}$ merupakan pengukuran warna kromatik campuran merahhijau, di mana $(\mathrm{a}+)$ adalah merah dan (a-) adalah hijau, sedangkan nilai $b^{*}$ merupakan pengukuran warna kromatik campuran kuning-biru, di mana (b+) adalah kuning dan (b-)adalah biru (Asmediana et al., 2017).

\begin{abstract}
Analisis Data
Data yang diperoleh dianalisis menggunakan metode Analysis of Varians (ANOVA) dengan taraf nyata 5\%. Jika terdapat pengaruh, maka dilanjutkan dengan menggunakan Duncan Multiple Range Test (DMRT) untuk megetahui perbedaan antar perlakuan. Analisis data dihitung dengan bantuan komputer program SPSS for windows versi 22.
\end{abstract}

\section{HASIL DAN PEMBAHASAN}

\section{Total Asam}

Hasil analisis total asam pada Tabel 1 menunjukkan adanya peningkatan dari 12 jam lama fermentasi yang paling singkat hingga lama fermentasi paling lama yaitu 48 jam. Nilai rerata total asam pada water kefir belimbing manis yang difermentasi dengan lama fermentasi yang bervariasi berkisar antara $0,148 \%-1,116 \%$. Adanya peningkatan total asam pada perlakuan 12 jam hingga 48 jam water kefir belimbing manis dapat disebabkan bertambahnya waktu fermentasi. Total asam sangat berkaitan erat dengan total bakteri asam laktat, semakin lama waktu fermentasi maka semakin banyak pula bakteri asam laktat yang tumbuh, sehingga bakteri asam laktat yang semakin banyak dapat menghasilkan asam laktat yang semakin banyak pula dari proses metabolismenya. Hal ini sesuai dengan pendapat Yusriyah \& Agustini (2014) yang menyatakan bahwa semakin lama waktu fermentasi dan semakin banyak konsentrasi bibit kefir yang ditambahkan maka menghasilkan semakin banyak pula asam dari proses fermentasi tersebut.

Asam laktat yang terdapat pada water kefir belimbing manis berasal dari perombakan sukrosa dan fruktosa yang berasal dari gula yang ditambahkan dan sari buah belimbing menjadi asam laktat oleh bakteri asam laktat melalui proses glikolisis. Hal ini sesuai dengan pendapat Muizuddin \& Zubaidah (2015) yang menyatakan bahwa pada proses fermentasi, khamir akan memecah sukrosa menjadi glukosa dan fruktosa yang selanjutnya glukosa akan dipecah oleh khamir dan bakteri asam laktat untuk membentuk alkohol dam asam laktat. Asam laktat yang 
dihasilkan dari proses perombakan sukrosa dan fruktosa oleh bakteri asam laktat menyebabkan rasa asam pada water kefir belimbing manis. Hal ini sesuai dengan pendapat Barus et al. (2019) yang menyatakan bahwa semakin banyak asam laktat yang dihasilkan dari proses fermentasi menyebabkan produk memiliki rasa yang semakin asam dan $\mathrm{pH}$ yang semakin rendah.

Tabel 1. Kandungan Total Asam Water Kefir Buah Belimbing Manis dengan Lama Fermentasi yang Berbeda

\begin{tabular}{cc}
\hline Lama & $\begin{array}{c}\text { Rerata Nilai } \\
\text { Total Asam }(\%)\end{array}$ \\
\hline Fermentasi & $0,148 \pm 0,010^{\mathrm{a}}$ \\
12 jam & $0,239 \pm 0,012^{\mathrm{b}}$ \\
$24 \mathrm{jam}$ & $0,527 \pm 0,039^{\mathrm{c}}$ \\
36 jam & $1,116 \pm 0,039^{\mathrm{d}}$ \\
\hline 8 jam & kecil yang berbeda
\end{tabular}
menunjukkan perbedaan yang nyata $(\mathrm{p}<0,05)$

\section{Total Bakteri Asam Laktat (BAL)}

Hasil analisis total bakteri asam laktat pada Tabel 2 menunjukkan adanya peningkatan dari perlakuan 12 jam dengan lama fermentasi yang paling singkat yaitu 24 jam hingga perlakuan 48 jam dengan lama fermentasi paling lama yaitu 48 jam. Nilai rerata total asam pada water kefir belimbing manis yang difermentasi dengan lama fermentasi yang bervariasi berkisar antara $0,148 \%-1,116 \%$. Adanya peningkatan total asam pada dapat disebabkan karena bertambahnya waktu fermentasi, semakin lama waktu fermentasi maka semakin tinggi pula total BALnya. Hal ini disebabkan oleh adanya makanan yang cukup untuk hidup dan berkembang biak bakteri asam laktat, bakteri asam laktat membutuhkan nutrisi atau makanan yang kemudian akan digunakan sebagai sumber energi untuk hidup dan berkembang biak, nutrisi bakteri asam laktat dalam water kefir belimbing manis berasal dari gula yang ditambahkan dan dari sari buah belimbing. Hal ini sesuai dengan pendapat A'yuni et al. (2020) yang menyatakan bahwa semakin lama waktu fermentasi akan menyebabkan semakin banyak pula gula yang dirombak oleh bakteri asam laktat untuk pertumbuhannya.

Sukrosa yang berasal dari gula yang ditambahkan akan dirombak oleh khamir menggunakan enzim invertase sehingga menghasilkan glukosa dan fruktosa, kemudian glukosa dan fruktosa yang telah dirombak dari fruktosa dari sari belimbing akan dimanfaatkan oleh bakteri asam laktat dan khamir melalui proses glikolisis untuk menghasilkan asam piruvat, asam piruvat yang diperoleh dari proses glikolisis akan diubah menjadi asam laktat oleh bakteri asam laktat dan akan diubah menjadi alkohol dan karbon dioksida oleh khamir. Hal ini sesuai dengan pendapat Muizuddin \& Zubaidah (2015) yang menyatakan bahwa selama proses fermentasi glukosa akan dimanfaatkan khamir dan bakteri asam laktat untuk membentuk alkohol dan asam laktat. Fermentasi yang terlalu lama juga dapat menurunkan total BAL.

Tabel 2. Total BAL Water Kefir Buah Belimbing Manis dengan Lama Fermentasi yang Berbeda

\begin{tabular}{cc}
\hline Lama & Rerata Nilai Total \\
Fermentasi & BAL $($ Log CFU/ml $)$ \\
\hline 12 jam & $7,102 \pm 0,214^{\mathrm{a}}$ \\
24 jam & $7,477 \pm 0,265^{\mathrm{b}}$ \\
36 jam & $8,241 \pm 0,121^{\mathrm{c}}$ \\
48 jam & $8,784 \pm 0,222^{\mathrm{d}}$ \\
\hline a,b,c,d & superkrip huruf kecil yang berbeda \\
menunjukkan perbedaan yang nyata $(\mathrm{p}<0,05$
\end{tabular}

\section{Warna LAB}

Pada Tabel 3 dapat diketahui bahwa berdasarkan uji statistik ANOVA yang telah dilakukan terdapat pengaruh nyata pada nilai $\mathrm{L}$ (Lightness) atau kecerahan warna semua perlakuan, kecuali perlakuan 24 jam dan 36 jam, 36 jam dan 48 jam yang tidak berbeda nyata. Rerata nilai kecerahan tertinggi terdapat pada perlakuan 48 jam yaitu 30,849, sedangkan rerata nilai kecerahan terendah terdapat pada perlakuan 12 jam yaitu 26,356. Perlakuan 12 jam menunjukkan kecerahan yang paling rendah, hal ini diduga karena terjadi browning reaction yang meyebabkan warna lebih gelap. Browning reaction pada belimbing disebabkan oleh adanya kandungan polifenol pada sari belimbing yang bereaksi dengan oksigen dengan bantuan enzim polifenol oksidase sehingga menimbulkan warna yang lebih gelap. Hal ini sesuai dengan pendapat Trisnawati et al. (2013) yang menyatakan bahwa pembentukan warna coklat disebabkan oleh terjadinya reaksi oksidasi senyawa fenol dan polifenol oleh 
enzim fenolase dan polifenolase yang kemudian membentuk quinon yang kemudian berpolimerisasi membentuk melanin atau pigmen berwarna coklat. Nilai kecerahan pada sampel water kefir belimbing manis mengalami peningkatan menjadi semakin cerah seiring dengan bertambahnya waktu fermentasi. Hal ini disebabkan oleh karena semakin lama waktu fermentasi water kefir belimbing manis semakin asam yang dapat menyebabkan kerusakan pada enzim dan senyawa polifenol seperti tanin. Hal ini sesuai dengan pendapat Paiki et al. (2018) yang menyatakan bahwa keasaman yang semakin rendah dapat menyebabkan enzim mengalami denaturasi sehingga enzim menjadi tidak aktif dan tidak terjadi pencoklatan. Peningkatan kecerahan juga dapat dipengaruhi oleh berkurangnya total padatan terlarut yang dapat membuat water kefir belimbing menjadi lebih keruh, berkurangnya total padatan terlarut disebabkan oleh aktivitas mikroorganisme water kefir yang bekerja merombak padatan terlarut seperti gula yang ada pada water kefir belimbing manis menjadi asam laktat.

Berdasarkan Tabel 3 dapat diketahui bahwa hasil uji statistik ANOVA yang telah dilakukan terdapat pengaruh nyata pada nilai $a^{*}$ atau warna merah-hijau semua perlakuan, kecuali perlakuan 24 jam dan 36 jam serta 36 jam dan 48 jam yang tidak berbeda nyata. Rerata nilai kemerahan tertinggi terdapat pada perlakuan 48 jam yaitu $-0,440$, sedangkan rerata nilai kemerahan terendah terdapat pada perlakuan 12 jam yaitu $-2,356$. Perlakuan 12 jam menunjukkan kemerahan yang paling tinggi, hal ini disebabkan karena belimbing mengandung pigmen karoten yaitu pigmen yang membuat belimbing berwarna oranye. Hal ini sesuai dengan pendapat Dasgupta et al. (2013) yang menyatakan bahwa belimbing manis mengandung senyawa aktif berupa saponin, alkaloid, flavonoid, tanin, gallotanin, vitamin $\mathrm{C}, \beta$-sitosterol, campesterol, lupeol, isofucosterol, asam palmitat, asam oleat, asam lenoleat, kalsium, selulosa, hemiselulosa, mineral, phosphorous, zat besi, pektin, dan karotenoid. Penurunan nilai kemerahan menjadi lebih ke warna hijau yaitu dapat disebabkan karena kerusakan pigmen karoten akibat $\mathrm{pH}$ yang semakin rendah akibat produksi asam laktat yang semakin banyak oleh bakteri asam laktat. Hal ini sesuai dengan pendapat Mauliasari et al. (2019) yang menyatakan bahwa karotenoid akan mengalami penurunan sebanyak $84 \%$ dalam lingkungan yang memiliki $\mathrm{pH}$ asam dan mengalami penurunan sebanyak $15 \%$ dalam lingkungan yang memiliki $\mathrm{pH}$ basa.

Berdasarkan Tabel 3 dapat diketahui bahwa hasil uji statistik ANOVA yang telah dilakukan tidak terdapat pengaruh nyata pada nilai $b^{*}$ atau kuning-biru. Nilai $b$ water kefir belimbing manis berkisar antara 7,596 - 7,943 tidak jauh berbeda antara perlakuan satu dengan perlakuan lain. Nilai $b^{*}$ yang bernilai positif menunjukkan warna dominan kuning dibanding dengan warna biru. Sukmamei et al. (2015) menyatakan bahwa warna kuning terbentuk karena adanya pigmen flavonoid dalam kandungan sari belimbing manis.

Tabel 3. Hasil Analisis Warna L*a*b* Water Kefir Buah Belimbing Manis dengan Lama Fermentasi yang Berbeda

\begin{tabular}{cccc}
\hline Lama Fermentasi & $\left(\mathrm{L}^{*}\right)$ & $\left(\mathrm{a}^{*}\right)$ & $\left(\mathrm{b}^{*}\right)$ \\
\hline 12 jam & $26,356 \pm 1,492^{\mathrm{a}}$ & $-0,440 \pm 0,712^{\mathrm{a}}$ & $7,778 \pm 0,512^{\mathrm{a}}$ \\
24 jam & $28,732 \pm 0,901^{\mathrm{b}}$ & $-1,679 \pm 0,464^{\mathrm{b}}$ & $7,659 \pm 0,453^{\mathrm{a}}$ \\
36 jam & $29,818 \pm 0,867^{\mathrm{bc}}$ & $-2,177 \pm 0,207^{\mathrm{bc}}$ & $7,943 \pm 0,603^{\mathrm{a}}$ \\
$48 \mathrm{jam}$ & $30,849 \pm 0,629^{\mathrm{c}}$ & $-2,356 \pm 0,247^{\mathrm{c}}$ & $7,596 \pm 0,112^{\mathrm{a}}$ \\
\hline
\end{tabular}

a,b,c superskrip yang berbeda pada kolom yang sama menunjukkan perbedaan yang nyata $(\mathrm{p}<0,05)$

\section{KESIMPULAN}

Pada proses fermentasi water kefir blimbing manis, semakin lama fermentasi (1248 jam) dapat meningkatkan total asam, total bakteri asam laktat, dan intensitas warna kecerahan water kefir, namun menurunkan intensitas warna merah water kefir blimbing manis.

\section{DAFTAR PUSTAKA}

A'yuni, N.M., Hidaayah, N. \& Pratiwi, V.N. 2020. Analisis perbedaan waktu fermentasi terhadap kadar probiotik dan aktivitas antioksidan pada minuman probiotik sari buah stroberi (Fragaria anannassa). Sport and Nutrition Journal, 2(2): 49-55. 
Asmediana, A., Hastuti, P. \& Supriyadi. 2017. Perubahan komponen rasa gurih dalam cabuk yang mengalami penyimpanan dan pemanasan berulang. Agroindustrial Technology Journal, 1(1): 1-9.

Barus, E.P.B., Rizqiati, H. \& Bintoro, V.P. 2019. Total bakteri asam laktat, nilai ph, total padatan terlarut, dan sifat organoleptik cocofir dengan lama fermentasi yang berbeda. J. Teknologi Pangan, 3(2); 247-252.

Berawi, K.N. \& Pasya, A.V. 2016. Pengaruh pemberian jus belimbing manis (Averrhoa carambola L.) untuk menurunkan tekanan darah. J. Majority. 5(1): 23-27.

Dasgupta, P., Chakraborty, P. \& Bala, N.N. 2013. Averrhoa carambola. Intenational Journal of Pharma Researchand Review, 2(7): 54-63.

Insani, H., Rizqiati, H \& Pratama, Y. 2018. Pengaruh variasi konsentrasi sukrosa terhadap total khamir, total padatan terlarut, kadar alkohol dan mutu hedonik pada water kefir buah naga merah (Hyloreceus polyrhizus). J. Teknologi Pangan, 2(2): 90-95.

Lestari, M.W., Bintoro, V.P. \& Rizqiati, H. 2018. Pengaruh lama fermentasi terhadap tingkat keasaman, viskositas, kadar alkohol, dan mutu hedonik kefir air kelapa. J. Teknologi Pangan, 2(1): 6-13.

Mauliasari, E.S., Agustini, T.W. \& Amalia, U. 2019. Stabilisasi fikosianin spirulina platensis dengan perlakuan mikro enkapsulasi dan $\mathrm{pH}$. J. Pengolahan Hasil Perikanan Indonesia, 22(3): 526534.

Muizuddin, M. \& Zubaidah, E. 2015. Studi aktivitas antibakteri kefir teh daun sirsak (Annona muricata linn.) dari berbagai merk teh daun sirsak dipasaran. J. Pangan dan Agroindustri, 3(4): 1662-1672.

Ningsih, D.R., Bintoro, V.P. \& Nurwantoro. 2018. Analisis total padatan terlarut, kadar alkohol, nilai ph dan total asam pada kefir optima dengan penambahan high fructose syrup (HFS). J. Teknologi Pangan, 2(2): 84-88.
Paiki, S.N.P., Sarungallo, Z.L., Latumahina, R.M.M., Susanti, C.M.E., Sinaga, N.I. \& Irbayanti, D.N. 2018. Pengaruh blansing dan perendaman asam sitrat terhadap mutu fisik dan kandungan gizi tepung buah pandan tikar (Pandanus tectorius Park.). J. Agritechnology, 1(2): 76-83.

Purba, A.P., Dwiloka, B. \& Rizqiati, H. 2018. Pengaruh lama fermentasi terhadap bakteri asam laktat (BAL), viskositas, aktivitas antioksidan,dan organoleptik water kefir anggur merah (Vitis vinifera L.). J. Teknologi Pangan, 2(1): 49-51.

Rohman, A., Dwiloka, B. \& Rizqiati, H. 2019. Pengaruh lama fermentasi terhadap total asam, total bakteri asam laktat, total khamir dan mutu hedonik kefir air kelapa hijau (Cocos nucifera). $J$. Teknologi Pangan, 3(1): 127-133.

Soetikno, N., Ristiarini, S. \& Khairina, R 2018. Sifat sensoris, kimia dan warna, ronto pada konsentrasi garam dan nasi yang berbeda. J. Pengolahan Hasil Perikanan Indonesia, 21(1): 85-91.

Sukmamei, E.M., Ika, E., Pratiwi, E., Fajarwati \& Listiyanti, H. 2015. Uji Kualitatif Flavonoid dalam Belimbing manis (Averrhoa carambola L.). Akademi Analisis Kesehatan Nasional. Surakarta.

Sutedjo, K.S.D. \& Nisa, F.C. 2015 Konsentrasi Belimbing manis (Averrhoa carambola L) dan Lama Fermentasi terhadap karakteristik Fisikokimia dan Mikrobiologi Yogurt. J. Pangan dan Agroindustri, 3(2): 582593.

Trisnawati, T., Andesti, D. \& Saleh, A. 2013. Pembuatan kitosan dari limbah cangkang kepiting sebagai bahan pengawet buah duku dengan variasi lama pengawetan. J. Teknik Kimia, 2(19): $17-25$.

Wiradona, I \& Prasko, P. 2018. Efektivitas mengkonsumsi buah nanas (Ananas comosus) dan buah belimbing (Averrhoa carambola L.) terhadap skor plak. J. Kesehatan Gigi, 5(1): 16-23.

Yusriyah, N.H. \& Agustini, R. 2014. Pengaruh waktu fermentasi dan konsentrasi bibit kefir terhadap mutu kefir susu sapi. $J$. Kimia UNESA, 3(2): 53-57. 